\title{
Reflections on (Re)making History
}

\section{African American Acupuncturists and the Archives of Tolbert Small}

\author{
Eana Meng | ORCID: 0000-0002-3667-6585 \\ Harvard Medical School, Boston, MA, USA | Department of History \\ of Science, Harvard University, Cambridge, MA, USA \\ eanameng@hms.harvard.edu
}

\begin{abstract}
Who and what makes history? This essay describes how physician-activist Tolbert Small (b. 1942) has been collecting, preserving, and recording his own history, as well as of those around him. Small has been practicing medicine in California's San Francisco Bay Area since 1968, serving a diversity of patients: from thousands of community members to revolutionaries such as Angela Davis and George Jackson. A physician for the Black Panther Party from 1970 to 1974, Small joined the party's 1972 delegation to China, where he witnessed acupuncture. He then integrated the practice into his medical toolkit upon returning home. Small's personal archives document an important chapter of American social and medical history. His stories, along with those of the revolutionaries who introduced acupuncture into New York City's Lincoln Detox Center during the 1970s, ask us to revisit conventional historical narratives as well as the way in which acupuncture history is made.
\end{abstract}

\section{Keywords}

Tolbert Small - medical activism - Black Panther Party - acupuncture - archives Lincoln Detox

In December of 2018 I emailed Dr. Tolbert Small, a physician who had formerly been a doctor for the Black Panther Party (BPP) from 1970 to 1974. I was conducting my undergraduate thesis research on contemporary acupuncture, and I had become aware of the role that Black revolutionaries played in developing new acupunctural protocols. When I came across Small's website, 
"The People's Doctor,"1 I hoped that he could tell me more. He responded warmly, happy to discuss his experiences. Small first encountered acupuncture on a seven-week trip to China in 1972 with a BPP delegation. As a history enthusiast himself, he said he had a habit of keeping ephemera and gladly helped with historical research however he could. He had a few documents from his trip to China that he found as he was cleaning out his garage, and he invited me to visit him at his home in Oakland, California. I arrived to learn that a tree had recently fallen on his home of nearly four decades. The room of his temporary residence was stuffed with boxes, including some from his garage, and we cleared a space to sit down.

Small brought out the suitcase he had taken to China, its brown leather fraying as he dusted it off. Inside, there was a carousel slide tray, holding images from his time in China and the slides of an acupuncture talk he had begun presenting in 1998, titled "Traditions of Healing: Acupuncture." He showed me the accompanying text of his talk, where he writes about his experiences in China watching acupuncture anesthesia and provides a literature review of the neurophysiological research behind acupuncture. Small himself also wrote two papers on acupuncture in 1974, and he showed me copies of American Journal of Acupuncture, the journal in which they were published. ${ }^{2}$ There were also four cassette tapes of recordings, amounting to about four hours, which he played for me. Sounds of a lecture hall filled the room, and a woman's voice, speaking in Chinese-accented English, described a thyroidectomy using acupuncture anesthesia, schistosomiasis control, and later the benefits of integrative medicine. His suitcase also held a journal, with roughly 100 pages filled with his diary entries of his six-week trip to China beginning on March 7, 1972. Small read the first entry aloud to me, describing how the BPP delegates had trouble with American authorities when departing the United States. Stuffed within the journal were also pamphlets of Chinese medicine advertisements such as ginseng royal jelly (renshen fengwangjiang 人参蜂王浆) - as well as a packet of official photos handed to each delegate by their Chinese tour guides. In addition to the suitcase, he said, there were other items from China - books, acupuncture needles, electroacupuncture machines, video recordings - somewhere in the garage.

1 See Tolbert Small: The People's Doctor, at: http://the-peoples-doctor.com/. Small is mentioned in Nelson $2013(97,122)$ for codirecting the BPP's national sickle cell anemia project. The 1972 trip to China is also mentioned, briefly on pp. 70-71. See also Small and Cole 2005; Schiller 2008; Meng 2019. Small's work has been more documented by journalists; see "Dr. Tolbert Small: Journey of a People's Doctor" 2002; Burt 2006; Chang 2018; Wang 2018.

2 See Small 1974a, 1974b. 
These materials are exciting not only because they are well preserved but also because they illustrate a history that is largely absent from conventional accounts of Chinese medicine in America. While a few scholars and journalists who have worked on the Black revolutionary movements and the history of American acupuncture have known about Small's story, it has been omitted from mainstream narratives. Instead, New York Times reporter James Reston's report of postoperative acupuncture care in Beijing in 1971 is credited for propelling acupuncture's dissemination into non-Asian communities in the United States. ${ }^{3}$ Reston's story is repeatedly told and his visibility reinforced in accounts by American schools of Chinese medicine, leading biomedical institutions, mainstream media outlets, and academics. ${ }^{4}$ Far less known are the activities of American Black revolutionaries and their associates, such as Small, who predate or parallel Reston and who have introduced acupuncture to thousands of patients - especially those from communities of color - since the 1970s.

While never a formal member of the BPP, Small directed the BPP's George Jackson People's Free Medical Clinic in Berkeley, California. In 1972 Small traveled to China for seven weeks as part of the 1972 в PP delegation which included twenty people: ten formal BPP members and ten community members. ${ }^{5}$ Huey Newton, cofounder of the BPP, had selected the cohort in hopes of

representing various ethnic groups, and spanning several generations, [where] the group became one, transformed into a delegation of American people, who had come from their different walks of life to work and live together under the tutelage of the Black Panther Party, as guests of the People's Republic of China ... ${ }^{6}$

In China, Small witnessed acupuncture being practiced in hospitals and rural clinics. Inspired by the barefoot doctors to bring integrative medicine into American communities, he taught himself acupuncture when he returned home. His self-needling sessions were also joined by other volunteers at the George Jackson clinic, including David Bacon, who subsequently commissioned an English translation of a PRC acupuncture text and asked Small to

3 See Reston 1971.

4 See Harris 2019; Johnson 2016; American College of Traditional Chinese Medicine, n.d.; Mount Sinai Health System, n.d.

5 Small was considered a member of the community group, and he was the only physician on the trip.

6 See "Progressive Americans" 1972. 
write its introduction. ${ }^{7}$ "The barefoot doctors learned acupuncture by doing it on themselves, and so we just did it on ourselves as well," Small explains. ${ }^{8}$ Over the past five decades, he estimates, he has treated thousands of underserved patients in the San Francisco Bay Area with acupuncture in his general practice, motivated by the B PP's signature call to "serve the people, body and soul."

During the 1970s, Small's use of acupuncture as a means to serve his community was paralleled by the efforts of radicals and members of the Black revolutionary movement in the South Bronx in New York City. Small and these East Coast revolutionaries were not connected in the early 1970 and did not influence each other's uptake of acupuncture - rather, they were simultaneous and independent enterprises. Prominent on the East Coast was Mutulu Shakur, a member of the Republic of New Afrika who worked alongside members of many different organizations, including the Harlem and Bronx chapters of the ВРP. Shakur was introduced to acupuncture by his friend and well-known Japanese American activist Yuri Kochiyama in $1970 .{ }^{10}$ Compelled by this nonchemical medical intervention, Shakur read about ear acupuncture's detoxification potential in articles about a Bangkok doctor's work, and later, research in Hong Kong by Hsiang-Lai Wen, a neurosurgeon..$^{11}$ Shakur was an instructor at the Lincoln Detox Center, a community healthcare program established in 1970 to help marginalized communities combat addiction during the height of

This book was given the English title Basic Acupuncture Techniques. For an image of its title page and additional background information, see Meng 2021b, 286-87. For more on Bacon's recollection of this time, see Burton-Rose and Wu 2021, 255.

8 Tolbert Small, interview with the author, February 9, 2019.

9 This party slogan was inspired directly by Mao Zedong's speech entitled "Serving the People," which featured in Quotations from Mao Tse-Tung, also known as the "Little Red Book," which was widely read by the BPP. See chap. 17 in Mao 1967. The estimate of the number of Small's patients comes from the medical records of his private practice, the Harriet Tubman Medical Office. He has also worked for other clinics and hospitals in the Bay Area.

10 Shakur 2018. The Republic of New Afrika was an organization that advocated for the creation of a separate nation for the Black community with several Southern states (see Onaci 2020). While he had collaborated with the BPP as he shared key values, Shakur was never a member. Kochiyama (1921-2014) was a prominent civil rights activist who advocated for reparations for Japanese American internees (civilians who were incarcerated under President Franklin D. Roosevelt's Executive Order 9066 in World War II) and their families. She worked closely with preeminent Black leaders such as Malcolm X, as she was active in opposing the oppression of all minorities. See Kochiyama 1994, 2004; Fujino 2005.

11 Porzig 2013; see also "Hong Kong Doctors Use Acupuncture to Relieve Addicts' Withdrawal Symptoms" 1973, which reports on Wen and Cheung 1973. 
the South Bronx's heroin epidemic. ${ }^{12}$ The Lincoln team, which was an alliance of Black, Latinx, and white revolutionaries, offered methadone maintenance, but it remained deeply skeptical of biomedical interventions and immediately took an interest in acupuncture. ${ }^{13}$ In 1972 an acupuncture program was formally established, and tens of thousands of patients were treated within the first year. ${ }^{14}$ Shakur and other members of the Lincoln team, such as Young Lords activist Walter Bosque del Rio, would, in 1976, receive doctorates in acupuncture from the Montreal Institute in Traditional Chinese Medicine, where they were trained by Oscar and Mario Wexu. ${ }^{15}$

The Lincoln group provided training in acupuncture and politics as a means of building up a self-empowered "barefoot doctor acupuncture cadre."16 Their innovations included identifying certain points on the ear to needle for treating drug addiction. In 1985 these and other points were formalized by Michael Smith (1942-2017) into a five-point ear acupuncture treatment called the National Acupuncture Detoxification Association (NADA) protocol. The NADA organization was also simultaneously founded. Smith, who had worked alongside Shakur and Bosque del Rio since the early 1970s, had become the director of a relocated Lincoln Center (now called Lincoln Recovery) in 1978. More than 25,00o people worldwide have been trained in the NADA protocol, including community practitioners, first responders, and incarcerated persons, for treating addiction, anxiety, stress, and other behavioral health conditions. ${ }^{17}$

12 Porzig 2013; see also Melendez 2003, 176-78; Burrough 2015, 452; Reverby 2020, 92-96, 109-11; Bliss 2018; Donovan 2020.

13 Some literature such as Burrough 2015 suggest that white physician Richard Taft, who was part of the Lincoln team working on the drug program, introduced acupuncture to the clinic (452). However, this contradicts accounts by many other figures at Lincoln in the early 1970s, such as Shakur and Bosque del Rio. Shakur was most likely the first to introduce acupuncture to the clinic, and it was then sustained by the interest of the other members of the team. Taft's role was likely as someone who had an interest in Chinese medicine and encouraged its use. Later practitioners at Lincoln recall that the white doctors were often strategically credited by Lincoln staff as a means of legitimization with government officials and the public.

14 Jones 2015; see also Voyles, Carter, and Cooley 2020.

15 Mario Wexu, in discussion with the author, October 22, 2020. The Young Lords was a revolutionary group consisting mainly of Puerto Ricans who shared many values and practices with the врг. Bosque del Rio played an instrumental role in the development of the acupuncture program as he was already practicing tai chi prior to the establishment of Lincoln Detox. He advocated for its use, found practitioners in New York's Chinatown to work with, and helped explain Chinese medicine concepts to the others. See Shakur 2000; Blanchard 2018; Bliss 2018.

16 Shakur 2014.

17 Stuyt, Voyles, and Bursac 2018, 20; there are likely much more than 25,0oo people practicing the five-point ear acupuncture protocol. This number only refers to practitioners 
Standard accounts of the protocol's history by the NADA organization itself (or related community ear acupuncture groups) often credit Smith, a white psychiatrist, with being the inventor of the protocol, while the key roles of Shakur and the early Lincoln team remain largely unrecognized. A few individual practitioners and creatives, however, have worked to keep the early history alive. ${ }^{18}$

It was thanks to the work of one such practitioner that I learned of Shakur and then about Small. In the fall of 2018, as part of research for my undergraduate thesis, ${ }^{19}$ I was observing patients at an opioid recovery center in New Hampshire. I saw that the practitioner treated each person by inserting needles into the same five points in the ear, asking only a few questions about the patient's condition. It quickly became clear that this was a therapy notably distinct from those described in standard Chinese medical texts or employed by practitioners in the PRC, such as the doctors on the maternal side of my family in Shandong or those I observed during my research in Shanghai. When I inquired about the origins of this NADA protocol, the acupuncturist handed me Greg Jones's pamphlet titled A Radical History of Acupuncture in America. Jones is part of the People's Organization of Community Acupuncture (POCA) movement, which was founded in 2002 to advocate for accessible and affordable group acupuncture. ${ }^{20}$ In this pamphlet, whose imagined readership is mainly patients and POCA members, Jones lays out the story of the use of acupuncture by the early Lincoln revolutionaries. ${ }^{21}$ His pamphlet was an attempt to write the revolutionaries back into the history of American innovations in acupuncture.

The works of Tolbert Small and Mutulu Shakur are not hidden - in fact, a simple Google search with keywords such as "Black," "revolutionaries," and "acupuncture" allowed me to find and contact them or people close to them

who have been trained directly by the NADA organization. SMART UK (Substance Misuse Acupuncture Register and Training), cofounded by Sue Cox and Kim Wagner in the mid1990s, has trained over 20,00o people working in the addiction field. While they pay homage to early-197os Lincoln revolutionaries such as Shakur, Cox and Wagner are explicit that SMART UK is a distinct organization from NADA (the organization founded in 1985).

18 See Jones 2015; Shelton 2017; Bliss 2018; Donovan 2020. Jones and Shelton are both community acupuncturists and created a pamphlet and postcards, respectively, honoring the acupuncture work by revolutionaries such as Shakur. Bliss and Donovan have each created documentaries on the Lincoln Detox history, with a specific focus on the use of acupuncture.

19 Meng 2019.

$20 \quad$ Rohleder et al. 2009.

21 Jones 2015. 
within days. ${ }^{22}$ However, these histories have yet to be properly integrated into academic and public narratives, let alone standard histories of acupuncture's spread into non-Asian communities in the United States. ${ }^{23}$ While the stories of Small and Shakur are well known within certain communities, they have been strikingly absent in others. Many NADA and related practitioners that I talked to in 2018-19 hardly knew Shakur's name. ${ }^{24}$ Shakur went underground in 1982 and was subsequently incarcerated in 1986 after being convicted in a federal conspiracy case whose charges included the liberation of Assata Shakur and involvement in a 1981 robbery of a Brinks armored truck. His disappearance from public view undoubtedly contributed to his disappearance from the history of acupuncture in the United States. ${ }^{25}$ Yet, even Small, who has continuously and actively practiced acupuncture in the Bay Area since 1972, and has written and spoken on the subject, remains little recognized by the acupuncture community in California and has appeared even less in the public narrative than Shakur and his colleagues have. ${ }^{26}$ Today, with increased pressure from practitioners, patients, and general community members in the wake of the Black Lives Matter movement of 2020, NADA, American acupuncture schools, and related organizations are making efforts to retrace the origin stories of the dissemination of acupuncture in the United States. Filmmakers

22 The Lincoln story has been featured in blog posts or online magazines, such as ones on Shakur (see "Mutulu Shakur: On the History of Acupuncture and COINTELPRO" 2008; Porzig 2013; Dandridge 2020). There has been more journalistic coverage in 2020. Shakur is currently imprisoned and can only be reached via letter correspondence. The Friends and Family of Mutulu Shakur, however, can be contacted by email. See Friends and Family of Mutulu Shakur 2020.

23 The Lincoln story and Shakur feature in Hinrichs and Barnes 2013, 296-98; Phan 2017, 254-258. As mentioned, Small's acupuncture work is briefly mentioned in Nelson 2013, 70-71.

24 As mentioned above, there was intensified coverage of the early Lincoln history in 2020. Due to the efforts of NADA and related organizations to recognize this history, I suspect that many more of its practitioners will have now heard about Shakur and his colleagues. Far more work, however, needs to be done to increase lasting awareness of these histories in the broader acupuncture community, academia, and public knowledge.

25 As of this writing, Shakur remains incarcerated, though his release was originally set to be in 2016. In early 2020 he was diagnosed with bone marrow cancer, and his legal team worked to petition for compassionate release, which was denied in November 2020. See Friends and Family of Mutulu Shakur 2020.

26 In an effort to bring Small's story to the forefront alongside the work of the Lincoln revolutionaries, I have written about them together, highlighting their simultaneous yet parallel uptake of acupuncture for similar reasons of serving and empowering their communities. See Meng 2021a. 
Jenna Bliss and Mia Donovan have led the effort in rewriting the early history of Lincoln into public consciousness. ${ }^{27}$

Meanwhile, the near half-century of relative invisibility of African Americans in prevailing histories of acupuncture has had lasting consequences. It is echoed in the tiny percentages of African American clients of acupuncture, where non-Hispanic Blacks have the lowest rates of utilization of complementary and alternative practices in the United States. ${ }^{28}$ Beyond rectifying a glaring omission in past and present accounts of Chinese medicine, the histories of Shakur and Small demonstrate the value of the new kind of scholarship called for by Volker Scheid and Sean Hsiang-lin Lei, one which focuses on the "fractured field of medical practice ... shaped by the needs, choices, and cultural histories of its local consumers." ${ }^{29}$ In other words, to study the development and manifestations of Chinese medicine necessarily requires us to ask: what forms does it take, where does it exist, who uses it, for whom, and why?

In Small's room there were several boxes of other ephemera, memorabilia, and documents from his career as a physician and activist. Many were from his time working with the BPP. Another several boxes were from the Harriet Tubman Clinic he founded with his then-wife, Anola Small, and contained medical records, letters, articles, and paintings. With pages fraying and pieces missing owing to house moves, these remarkable historical objects and the stories they carry with them have only been protected by Small's own love of history and belief in the importance of documenting. A humble man, he has still to fully realize how important his history and own archival work is to diverse fields from Chinese medicine to African American history. Roughly fifteen years ago, English professors Drs. Christy Rishoi and Larry Juchartz of Mott Community College in Michigan set up Dr. Small's website after discovering his poem "America" on It's About Time, a virtual archive of the вPР curated by Billy X. Jennings, a former Party member. ${ }^{30}$ Realizing that they were speaking with "living history," Juchartz and Rishoi created a Google site for Small with scans he sent in of his historical materials. ${ }^{31} \mathrm{~A}$ few years later, Juchartz encouraged Small to hire a professional website developer to manage the breadth of material, and "The People's Doctor" was born. ${ }^{32}$ Juchartz and Rishoi's efforts

\footnotetext{
27 Bliss 2018; Donovan 2020.

28 Clarke et al. 2015 .

29 Scheid and Lei 2014.

$30 \quad$ See Small, n.d.

31 For the original website, see Masks: The Collected Poems of Tolbert Jones Small at https:// sites.google.com/site/maskspoetryofdrtolbertsmall/Home.

32 This website is designed and managed by Ryan Copeland at Regroup Digital Solutions located in Detroit, Michigan.
} 
have allowed the public to have a window into these rich archives. Continuing with the spirit of accessibility, Small and his family, Rishoi, Juchartz, and I are now working together to preserve his materials, thinking through where they should be housed and how they can best embody the values that have animated Small's life and work: to uplift and empower marginalized communities.

Yet, it is not only Small's archives that lend critical insight and have historical weight; it is primarily Small himself - as an actor, witness, and living historical figure - who vivifies and, quite literally, completes the picture. We are generating new material in live time. This process is rooted in the ethos of equal participation and coproduction; Small is an (oral) historian in his own right, having documented his own history as well as others' for decades, interviewing his family members, patients, and revolutionary figures such as George Jackson and Assata Shakur. ${ }^{33}$ Where I suggest recording oral histories, his commentary about the archives, and filming his poetry, he suggests teaching me acupuncture and reviewing transcripts and role-playing the different actors as he fills in details; where he instructs me on questions to ask him and others, I inquire him on an endless number of specifics. It is impossible to capture an entire life, especially one as intricate and multitudinously layered as his, but I am convinced that we are giving it our best shot by conspiring together. In returning to the past and reflecting on the present, Small declares his greatest hope: "I want people to know their history."34

Small's voice and archival sources open a new avenue for research into the many ways that Asian medicine has been transmitted and transformed by people teaching and practicing it around the world. They emphasize how local variations are created by people who are embedded in a global, dynamic network. I have traveled around the United States and abroad to map these understudied connections, piecing together the various understandings of the 1972 China trip, tracing the transmission of the five-point ear acupuncture protocol, and learning of its local uses and meanings. ${ }^{35}$ In a prison in rural northern England, I sat among six young offenders - all white, younger than twenty, from communities with high rates of addiction - as they learned how to perform ear acupressure on themselves and each other. While they were surprised by the treatment's radical roots, they remarked on what felt common to them: the experiences of a marginalized community struggling with addiction, with little support from biomedicine. The other incarcerated men who had been using

33 See Small 1997, 2015.

34 Tolbert Small, interview with the author, December 13, 2020.

35 For a video presentation of this research hosted by the Harvard University Asia Center, see Meng 2020. 
the treatment for years remarked on the significance of being able to treat themselves, where acupressure gave them a means for self-empowerment. Despite differences in local cultures and needs, a common thread runs through these stories and the stories of Small and Shakur: the importance of agency, empowerment, and accessibility in the pursuit of health, especially for marginalized communities. This use of acupuncture to treat medical and social ills can be observed across space and time, from 1972 California to $2018 \mathrm{New}$ Hampshire, and 1973 New York to 2020 England. As Shakur recently told me: "There are so many parallels between the ' 70 os and now. The people have a right to natural healing." 36

In a time when we are reckoning with whose stories have been traditionally told, and how these narrative choices embody and perpetuate social inequity, these histories offer us a way forward. They lay down "desire lines" for future scholarship, and the direction that they point to can be described by one word: alliances. ${ }^{37}$ Shakur was part of the alliance-based Lincoln team working with Bosque del Rio and others; Small was part of an intentionally diverse delegation that symbolically represented an alliance of American people. Small, his family, Rishoi, Luchartz and I are an alliance working to preserve a history. What the revolutionaries believed and championed was that change was most possible if people of various backgrounds labored together toward one common goal. Similarly, an interdisciplinary endeavor by scholars, practitioners, living historical actors, and community members, across academic and institutional boundaries, may better advance the shared commitment to fostering and improving knowledge. If dominant narratives of Chinese medicine (or American history or medical activism) simply absorb the stories of Small and Shakur as singular, "interesting" examples of "Black revolutionaries using acupuncture," they would miss the point entirely. That is because these stories are the stories of revolution, civil rights, race, class, gender, (Chinese) medicine, American history, and more, all together. The histories of Small and Shakur synergistically bring together different fields, thus cocreating possibilities of new knowledge. By seeking and examining new histories, we discover new ways to do history itself. An exciting future lies ahead, as we learn and take part in how these stories - and others - (re)make history.

$3^{6}$ Mutulu Shakur, in discussion with the author, August 1, 2020. Note: the audio was not recorded due to legal restrictions. Quotation is based on notes and paraphrase.

37 My use of "desire lines" is inspired by Robson 2009, who borrowed this term from architects. 


\section{Acknowledgments}

I am very grateful to Yi-Li Wu and Daniel Burton-Rose for inviting me to contribute to this important issue of Asian Medicine, and for their time, efforts, and thoughtful intention. My gratitude, as always, to my interlocutors, and especially Dr. Tolbert Small; I am lucky to work with them.

\section{About the Author}

Eana Meng is a MD-PhD candidate at Harvard Medical School and the Department of History of Science at Harvard University. Her interests include the histories of complementary and alternative medicines. She has produced a video series and published articles on the revolutionary roots of American acupuncture and its global legacies.

\section{Bibliography}

American College of Traditional Chinese Medicine. n.d. "Chinese Medicine." https:// www.actcm.edu/chinese-medicine/. Accessed September 24, 2020.

Blanchard, Sessi Kuwabara. 2018. "How the Young Lords Took Lincoln Hospital, Left a Health Activism Legacy." Filter, October 30, 2018. https://filtermag.org/ how-the-young-lords-took-lincoln-hospital-and-left-a-health-activism-legacy/.

Bliss, Jenna, dir. 2018. The People's Detox. Documentary. 56 minutes. New York.

Burt, Cecily. 2006. "No Small Contribution: Doctor Helped Community." East Bay Times, October 5, 2006. https://www.eastbaytimes.com/2006/10/o5/no-small-con tribution-doctor-helped-community/.

Burrough, Bryan. 2015. Days of Rage: America's Radical Underground, the FBI, and the Forgotten Age of Revolutionary Violence. New York: Penguin Press.

Burton-Rose, Daniel, and Yi-Li Wu. 2021. "Acupuncture, the Black Panther Party, and People's Medicine: An Interview with Physician-Activist Tolbert Small." Asian Medicine 16, no. 2: 251-75.

Chang, Momo. 2018. "Sickle Cell: The Last Health-Care Frontier for Black Lives." East Bay Express, September 12, 2018. https://www.eastbayexpress.com/oakland/ sickle-cell-the-last-health-care-frontier-for-black-lives/Content?oid=20074752.

Clarke, Tainya C., Lindsey I. Black, Barbara J. Stussman, Patricia M. Barnes, and Richard L. Nahin. 2015. "Trends in the Use of Complementary Health Approaches Among Adults: United States, 2002-2012." National Health Statistics Reports 79: 1. 
Dandridge, Tenisha. 2020. "The Unusual Tale of Acupuncture, Racism, and African American History in the USA." DAO Labs, June 9, 2020, first posted 2016. https:// mydaolabs.com/blogs/the-way/acupuncture-racism.

Donovan, Mia, dir. 2020. Dope Is Death. Documentary. 82 minutes. Montreal, Canada: EyeSteelFilm.

“Dr. Tolbert Small: Journey of a People's Doctor." 2002. Revolutionary Worker 1139, February 17, 2002. http://the-peoples-doctor.com/archives/dr-tolbert-small-jour ney-of-a-peoples-doctor/.

Friends and Family of Mutulu Shakur. 2020. "Home." Mutulu Shakur. http://mutu lushakur.com/site/.

Fujino, Diane C. 2005. Heartbeat of Struggle: The Revolutionary Life of Yuri Kochiyama. Minneapolis: University of Minnesota Press.

Harris, Mitchell. 2019. "The Birth of Acupuncture: History of Acupuncture." Blog of Pacific College, October 24, 2019. https:/www.pacificcollege.edu/news/blog/2019/ o1/25/the-birth-of-acupuncture-history-of-acupuncture.

Hinrichs, TJ, and Linda L. Barnes, eds. 2013. Chinese Medicine and Healing: An Illustrated History. Cambridge, MA: Belknap Press of Harvard University Press.

“Hong Kong Doctors Use Acupuncture to Relieve Addicts' Withdrawal Symptoms." 1973. New York Times, April 5, 1973. https://www.nytimes.com/1973/o4/o5/archives/ hong-kong-doctors-use-acupuncture-to-relieve-addicts-withdrawal.html.

Johnson, Ian. 2016. “An Expert on Chinese Medicine, but No New Age Healer." New York Times, September 23, 2016. https://www.nytimes.com/2016/o9/24/world/asia/ chinese-medicine-paul-unschuld.html.

Jones, Greg. 2015. A Radical History of Acupuncture in America. St. Petersburg, Florida: St. Pete Community Acupuncture.

Kochiyama, Yuri. 1994. "The Impact of Malcolm X on Asian-American Politics and Activism." In Blacks, Latinos, and Asians in Urban America: Status and Prospects for Politics and Activism, edited by James Jennings, 129-42. Westport, CT: Praeger.

Kochiyama, Yuri. 2004. Passing It On. Los Angeles: University of California Los Angeles Asian American Studies Center Press.

Mao, Zedong. 1967. Quotations from Mao Tse-Tung, edited by Stuart R. Schram. New York: Praeger.

Melendez, Miguel. 2003. We Took the Streets: Fighting for Latino Rights with the Young Lords. New York: St. Martin's Press.

Meng, Eana. 2019. "Maoism in New Hampshire: The Black Panther Party's Use of Acupuncture." BA (Hons) thesis, Department of the History of Science, Harvard University.

Meng, Eana. 2020. "In the Hands of the Revolutionaries and Communities: A Social History of Acupuncture (A Two-Part Video Series)." Harvard University Asia Center, 
September 202O. https://asiacenter.harvard.edu/hands-revolutionaries-and-com munities-social-history-acupuncture-two-part-video-series.

Meng, Eana. 2021a. "Use of Acupuncture by 1970s Revolutionaries of Color: The South Bronx “Toolkit Care’ Concept.” American Journal of Public Health 111, no. 5: 896-9o6. https://doi.org/10.2105/AJPH.2020.306o8o.

Meng, Eana. 2021b. "Photo Essay: Bringing Acupuncture to the People: Tolbert Small in China and California." Asian Medicine 16, no. 2: 276-94.

"Mutulu Shakur: On the History of Acupuncture and COINTELPRO." 2008. Sundiata Acoli Freedom Campaign, July 18, 2008. http://www.sundiataacoli.org/mutulu-sha kur-on-the-history-of-the-use-of-acupuncture-by-revolutionary-health-workers-to -treat-drug-addiction-and-us-government-attacks-under-the-cover-of-the-counter intelligence-program-cointelpr-32.

Mount Sinai Health System. n.d. "Traditional Chinese Medicine." https://www .mountsinai.org/health-library/treatment/traditional-chinese-medicine. Accessed September 24, 2020.

Nelson, Alondra. 2013. Body and Soul: The Black Panther Party and the Fight Against Medical Discrimination. Minneapolis: University of Minnesota Press.

Onaci, Edward. 2020. Free the Land: The Republic of New Afrika and the Pursuit of a Black Nation-State. Chapel Hill: University of North Carolina Press.

Phan, Tyler. 2017. “American Chinese Medicine." PhD diss., University College London. Porzig, Molly. 2013. "Lincoln Detox Center: The People's Drug Program." The Abolitionist, July 1, 2013. https://abolitionistpaper.wordpress.com/2013/o3/15/lin coln-detox-center-the-peoples-drug-program/.

"Progressive Americans, Led By Panthers, Return from China." 1972. The Black Panther Intercommunal News Service, April 22, 1972, A-C.

Reston, James. 1971. "Now, About My Operation in Peking." New York Times, July 26, 1971. http://graphics8.nytimes.com/packages/pdf/health/1971acupuncture.pdf.

Reverby, Susan M. 2020. Co-conspirator for Justice: The Revolutionary Life of Dr. Alan Berkman. Chapel Hill: University of North Carolina Press.

Robson, James. 2009. Power of Place: The Religious Landscape of the Southern Sacred Peak (Nanyue 南获) in Medieval China. Cambridge, MA: Harvard University Asia Center.

Rohleder, Lisa, Skip Van Meter, Moses Cooper, Matthew Gulbransen, Joseph Goldfedder, and John Vella. 2009. Acupuncture Is like Noodles: The Little Red (Cook) Book of Working Class Acupuncture. Portland, OR: Working Class Acupuncture.

Scheid, Volker, and Sean Hsiang-lin Lei. 2014. "The Institutionalization of Chinese Medicine." In Medical Transitions in Twentieth-Century China, edited by Bridie Andrews and Mary Brown Bullock, 244-66. Indianapolis: Indiana University Press. 
Schiller, Emily Rose. 2008. "Community Health Activism of The Black Panther Party." BA (Hons) thesis, Department of History, University of Michigan. Archived at: https://www.lib.umich.edu/undergraduate-research-award/award-winners \#2011-2012.

Shakur, Mutulu. 2000. "In Honor of Walter Bosque." Mutulu Shakur, August 1, 2000. http://mutulushakur.com/site/200o/o8/in-honor-of-walter-bosque/.

Shakur, Mutulu. 2014. "The Use of Acupuncture by Revolutionaries: An Interview with Brother Tyehimba." Mutulu Shakur, August 31, 2014. http://mutulushakur.com/ site/1992/10/interview-on-acupuncture/.

Shakur, Mutulu. 2018. "2018 Interview about Acupuncture \& The Opioid Crisis." Mutulu Shakur, November 19, 2018. http://mutulushakur.com/site/2018/11/acu puncture-interview/.

Shelton, James. 2017. “Ancestors of Liberation Acupuncture! In Postcards!" People's Organization of Community Acupuncture, July 13, 2017. https://www.pocacoop .com/prick-prod-provoke/post/ancestors-of-liberation-acupuncture-in-postcards.

Small, Tolbert. n.d. "America." It's About Time. http://www.itsabouttimebpp.com/BPP _Poetry/poetry_tolbert_small_1.html. Accessed May 16, 2021.

Small, Tolbert J. 1974a. "The Neurophysiological Basis for Acupuncture." American Journal of Acupuncture 2, no. 2: 77-87.

Small, Tolbert J. 1974b. "Acupuncture Anesthesia: A Review." American Journal of Acupuncture 2, no. 3: 147-63.

Small, Tolbert J. 1997. “Assata Shakur: Interview by Dr. Tolbert Small." The Commemorator, December 1997, uploaded December 2018. http://the-peoples-doctor.com/wp -content/uploads/2018/12/interview-with-assata-shakur-1997.pdf.

Small, Tolbert J. 2015. “On Visiting George." San Francisco Bay View, July 29, 2015. https://sfbayview.com/2015/o7/on-visiting-george/.

Small, Tolbert J., and Lewis Cole. 2005. Columbia University Black Panther Project: Interview of Dr. Tolbert Small by Lewis Cole. Alexandria, VA: Alexander Street Press.

Stuyt, Elizabeth, Claudia Voyles, and Sara Bursac. 2018. "NADA Protocol for Behavioral Health. Putting Tools in the Hands of Behavioral Health Providers: The Case for Auricular Detoxification Specialists." Medicines 5, no. 1: 20. https://doi.org/10.339o/ medicines5010020.

Voyles, Claudia, Kenneth Carter, and Laura Cooley. 2020. "Back to the Future: The National Acupuncture Detoxification Association (NADA) Protocol Persists as an Agent of Social Justice and Community Healing by the People and for the People." Open Access Journal of Complementary \& Alternative Medicine 2, no. 4. https://doi .org/10.32474/OAJCAM.2O2O.02.000143. 
Wang, Mary. 2018. "The 'Barefoot Doctors' Serving America's Cities." Bloomberg City Lab, May 22, 2018. https://www.bloomberg.com/news/articles/2018-05-22/the-bare foot-doctors-serving-america-s-cities.

Wen, Hsiang-Lai, and S.Y.C. Cheung. 1973. "Treatment of Drug Addiction by Acupuncture and Electrical Stimulation." Asian Journal of Medicine 9: 138-41. 